\title{
Using of bioinformatics and computer morphometry in study of Fusarium spp. causing potato dry rot
}

\author{
Nadezhda Zhilinskaia ${ }^{1}$, Julia Bazarnova ${ }^{1}$, Aleksandr Shleikin ${ }^{2}$ \\ Liudmyla Peshuk ${ }^{3}$, Oleg Galenko ${ }^{3}$
}

\author{
1 - Peter the Great St. Petersburg Polytechnic University, St. Petersburg, Russia \\ 2 - ITMO University, St. Petersburg, Russia \\ 3 - National University of Food Technologies, Kyiv, Ukraine
}

\section{Keywords:}

Fusarium spp.

Potato

Dry rot

Mormphometry

Bioinformatics

Testing

\section{Article history:}

Received 03.04.2016

Received in revised

form 16.06.2016

Accepted 01.09.2016

\section{Corresponding \\ author:}

Nadezhda Zhilinskaia

E-mail:

jilinskie@mail.ru

\section{Abstract}

Introduction. The purpose of research - to evaluate the possibility of using the methods of computer morphometry and bioinformatic analysis in studying of reactive changes in Fusarium spp. causing potato dry rot.

Materials and methods. Tubers of "Nevski" potato with Fusarium contamination signs were selected. Three areas of the damaged tuber potatoes were studied: the epicenter of contaminated plant tissue; peripheral area of contamination; plant tissue outside of contamination epicenter. Morphological research and computer morphometry of fixed preparations of microorganisms stained by $1,0 \%$ methylene blue solution were made under magnification x 400, x 1000 .

Results and discussion. Macroconidium morphometric characteristics of Fusarium spp. (square, perimeter, length, number) were obtained by automatic image analyzer "Micros". The algorithm and the computer program based on morphometric analysis of Fusarium spp. macroconidium cells causing potato dry rot was created to study bioinformatic cell characteristics.

The following information characteristics of fungal cells have been calculated: $\mathrm{H}$ - information entropy characterizing the real structural diversity; $\mathrm{H}_{\max }$ - the storage capacity characterizing the maximum structural time-diversity of biological system; R (\%) information redundancy coefficient characterizing the relative organization of biosystem.

The Fusarium macroconidium cells have demonstrated low values of $\mathrm{H}(0,002)$ compared to $\mathrm{H}_{\max }(0,5)$. The values of $\mathrm{R}$ in Fusarium cells were $99,40 \%$ - 99,69\% thus demonstrated a high degree of orderliness and relative organization in microbial cellss. Our research proves the maximum adaptation level of Fusarium cells as parasites in biocenosis with plant cells. It should be expected that in the case of the reaction of Fusarium cells on chemical or biological preparations the value of $\mathrm{H}$ should increase up to values of $\mathrm{H}_{\max }$, and the value of $\mathrm{R}$ will decrease. It's may be occured as a result of disruption structural and functional integrity of Fusarium cell system.

Conclusions. The method of bioinformatic analysis of Fusarium spp. cells causing potato dry rot can be recommended as a testing system in development of new plant protecting preparations. 


\section{Introduction}

Safety of food and agricultural products during production and turnover is a keystone in development of food market in many countries [1].

The potato is one of the leading agricultural crops in many countries. The total volume of its production in EU countries in 2013 amounted to about 60 million tons [2]. Despite the fact that the potato is a high yielding culture, total number of potato tubers has significantly reduced in some unfavourable years. The main reason of the potato harvest decrease is the damage of the potato tubers by bacterial and fungal infections such as Rhizoctonia, phoma rot, late blight, Fusarium and others [3].

Fusarium dry rot is a second most common plant disease after late blight. Fusarium spp. belongs to the division Ascomycota and causes many important diseases. These fungi may contaminate food products with mycotoxins, threatening to animal and human health, can cause a wide spectrum of human infections, especially in immune compromised patients (cancer) or HIV positive patients [4, 5].

The fungal genus of Fusarium spp. are wide spread in all regions of Northern Hemisphere and other regions [6, 7, 8]. Fusarium sambucinum, Fusarium coeruleum, Fusarium solani App.et. Wr., Fusarium avenaceum are the main potato pathogens (Figure1).

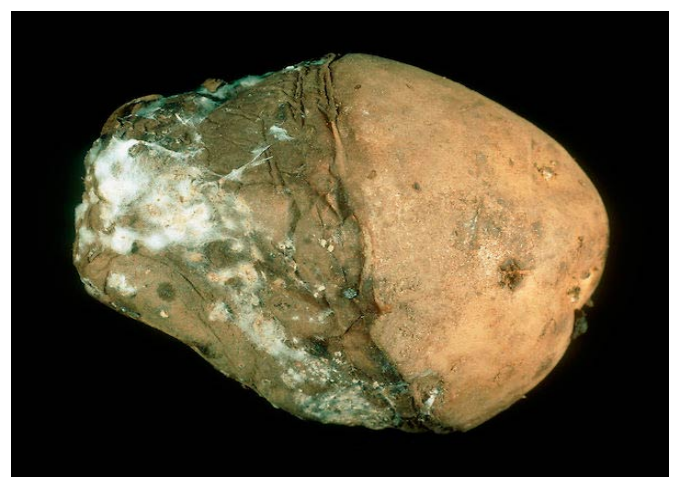

Figure1. Tuber contaminated by Fusarium spp. causing potato dry rot.

A new molecular method of PCR is widely used in science experiments together with traditional morphological and physiological research methods of Fusarium spp. [9, 10].

The following measures are used to prevent Fusarium plant contamination: mechanical cleaning of tubers, disinfection of storage containers, treatment storage period, keeping the optimum temperature, early diagnostics of tuber infection, chemical treatment of seed material $[11,12]$.

Biological protection of agricultural plants is one of the alternative methods to reduce soil damage against mineral fertilizers. Biologicals suppress the tissue pathogenic flora by their own microorganisms or plant biologically active extracts [13].

The chemical compound of plant tissue is a good growth medium for microorganisms. That's why the fungi of the genus Fusarium should be considered as one of the components of biological ecosystem.

New informative methods to characterize morphological and functional state of Fusarium cells are required in searching of chemical and biological plant protective means [14]. 
There is no data on using the bioinformatic modelling in study of morphofunctional state of Fusarium spp.

There are several articles on the bioinformatic status of human tissues [15]. It was demonstrated that the bioentropy reflects morphofunctional adaptive capacity of organism and is related to changes in bioinformatic status and development of pathological processes in tissues and organs $[16,17]$.

Our work was to explore the possibility of using bioinformatics and computer morphometry in studying the reactive changes of Fusarium spp. causing potato dry rot.

\section{Materials and methods}

Tubers of "Nevski" potato grown in the Leningrad region of Russia were selected as an object to study. The potato "Nevsky" belongs to intensive type of varieties and well responds to fertilizer application. Investigated tubers were in storage for 3 months after the harvest in 2015 , average storage temperature was $+18^{\circ} \mathrm{C}$, relative humidity was $75 \%$.

Sampling from potato lot was carried out in accordance with ISO 7002:1986. Potatoes tubers with Fusarium contamination signs were selected. The changes of tuber with dry rot were: drying up, shrivelling and falling off the epithelial tissue.

The tuber was cut with a knife along the longitudinal axis through the stolon and examined the tuber flesh. The flesh looked like a dry rotten black mass with voids, filled with fluffy mycelium of the fungus - the epicenter of contaminated plant tissue.

Three areas of the damaged potato tuber were studied:

- the epicenter of contaminated potato tuber tissue;

- peripheral area of potato tuber tissue contamination;

- potato tuber tissue outside the epicenter of contamination.

The qualitative method has been used to detect the presence or absence of Fusarium sp. in potato tissues (ISO 7218-2011). Microbiological study of tuber tissues was carried out using "imprint method" ("contact method") by analogy of horizontal sampling techniques from surfaces using contact plates (ISO 18593:2006). A glass slide was applied for 5-10 seconds to the each areas of contaminated potato tissues. Samples of potatoe tissues were stained by $1 \%$ methylene blue solution [18]. Morphological research of microorganism fixed preparations was made on microscope "Micros" (Austria), model MS 100 (XP), under magnification $\mathrm{x} 400$ or $\mathrm{x} 1000$.

Morphometric macroconidium cell characteristics of Fusarium spp. (square, perimeter, length, number) were obtained by automatic image analyzer "Micros". The quantification of microorganisms was made in 10 view fields for each sample [20].

Morphologic identification of fungi of the genus Fusarium was determined by curvature of macroconidium, the shape of the apical cells. The species identification of Fusarium according to the morphological characteristics of their macro - and microconidia wasn't studied.

The following information characteristics of fungal cells have been calculated:

- $\mathrm{H}$ - information entropy characterizing the real structural diversity.

- $\mathrm{H}_{\max }$ - the storage capacity characterizing the maximum structural time-diversity of biological systems.

- $\mathrm{R}(\%)$ - information redundancy coefficient that characterizing the true biosystem organization.

Statistical data processing was provided with program "STATGRAPHICS". 


\section{Results and discussion}

The results of recent study of morphofunctional state of yeast and bacterial producers of biotech products by bioinformatics and morphometric analysis show the usefulness of these methods in research of the adaptive reactions to some microorganisms [15]. The research purpose was to determine the possibility of using bioinformatics and computer morphometry to the fungal pathogens of valuable agricultural crops, including Fusarium causing potato dry rot.

The results of microscopic study of potato tuber tissues contaminated by Fusarium spp. are shown on Figure2.
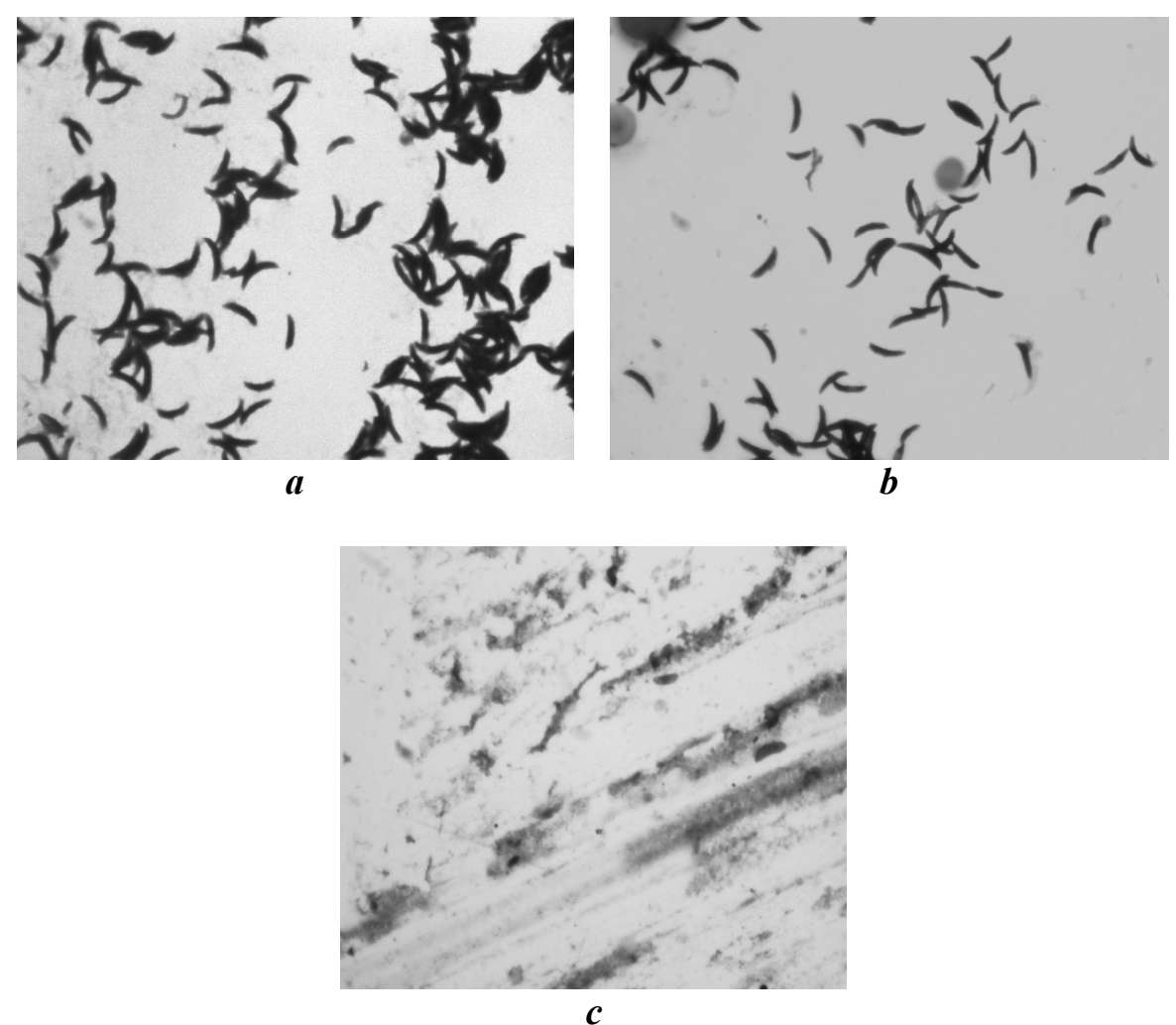

Figure 2. Conidia of the Fusarium spp. in potato tuber tissues:

$\mathrm{a}$ - the epicenter of contaminated potato tuber tissue;

$\mathrm{b}$ - peripheral area of potato tuber tissue contamination; $\mathrm{c}$ - potato tuber tissue outside the epicenter of contamination. Methylene blue. Magnification x 400 .

The maximum concentration of the Fusarium macroconidium cells was determined in the epicenter of contaminated potato tuber tissue (Figure 2-a). The amount of the Fusarium macroconidium cells decreased in the peripheral area of contamination (Figure 2-b). The Fusarium cells (only microconidium) were found in the plant tissue outside the epicenter of contamination in a single amount (Figure2-c). 
The macroconidium of Fusarium spp. were from fusiform to lanceolate, mostly with a visible three partitions. Cells in the central part are typically square. The apical cell is slightly elongated, gradually and evenly tapering, and somewhat curved (Figure 3).

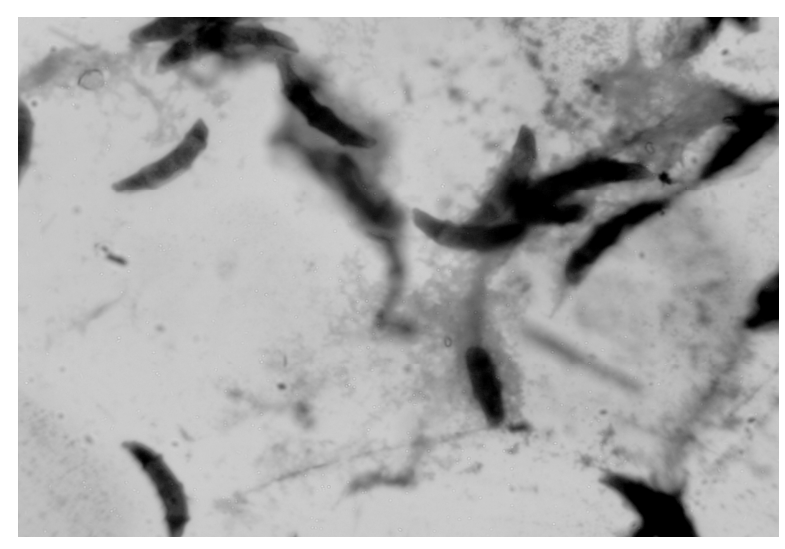

Figure 3. Macroconidium of Fusarium spp. causing potato dry rot. Methylene blue. Magnification x 1000.

The results of morphometric measurements of the Fusarium macroconidium cells in the epicenter of contaminated potato tuber tissue were: the area size was $30084,64 \mu \mathrm{m}^{2} \pm$ 0,02 , the cell perimeter $-996,15 \mu \mathrm{m} \pm 0,01$, the cell length $-\mu \mathrm{m} 416,31 \mu \mathrm{m} \pm 0,02$.

The results of morphometric measurements of the Fusarium macroconidium cells in the peripheral area of potato tuber tissue contamination were: the area size was 25670,66 $\mu \mathrm{m}^{2} \pm 0,03$, the cell perimeter $-1010,54 \mu \mathrm{m} \pm 0,01$, the cell length $-452,67 \mu \mathrm{m} \pm 0,04$.

The morphometric measurments of Fusarium microconidium cells in the plant tissue outside the epicenter of contamination weren't to carry.

The results obtained show that Fusarium cells have their individual morphometric characteristics in two zones of contamination. The area size of Fusarium cells in the epicenter of contaminated potato tuber tissue was 1,7 times larger then in the peripheral area of potato tuber tissue contamination.

Integral criteria of the morphofunctional state of Fusarium cells causing potato dry rot were obtained by using the basic concepts of thermodynamics and informatics: entropy $\mathrm{H}$ as a function of system state, the information redundancy [15].

The algorithm and the computer program based on morphometric analysis of Fusarium spp. were created to calculate cell characteristics such as information entropy $(\mathrm{H})$ and storage capacity $\left(\mathrm{H}_{\max }\right)$. Due to values of $\mathrm{H}$ and $\mathrm{H}_{\max }$, we've calculated the values of the information redundancy coefficient $(\mathrm{R}, \%)$ that characterizes a measure of the biological system reliability, i.e. its ability to resist external and internal effect factors.

The data of $\mathrm{H}, \mathrm{H}_{\max }$ and $\mathrm{R}$ for Fusarium cells causing potato dry rot are presented in Table 1. 
Informational characteristics of Fusarium cells causing potato dry rot

\begin{tabular}{|c|c|c|c|c|}
\hline Num & $\begin{array}{c}\text { Area of potato } \\
\text { tuber tissue }\end{array}$ & $\begin{array}{c}\text { Value of } \\
\text { information } \\
\text { entropy (H) }\end{array}$ & $\begin{array}{c}\text { Value of } \\
\text { storage } \\
\text { capacity }\left(\mathbf{H}_{\text {max }}\right) .\end{array}$ & $\begin{array}{c}\text { Value of } \\
\text { information } \\
\text { redundancy } \\
\text { coefficient } \\
\text { (R, \%) }\end{array}$ \\
\hline 1 & $\begin{array}{c}\text { The epicenter of } \\
\text { contaminated potato } \\
\text { tuber tissue }\end{array}$ & 0,002 & 0,5 & 99,69 \\
\hline 3 & $\begin{array}{c}\text { The peripheral area } \\
\text { of potato tuber } \\
\text { tissue } \\
\text { contamination }\end{array}$ & 0,002 & 0,5 & 99,4 \\
\hline $\begin{array}{c}\text { The potato tuber } \\
\text { tissue outside the } \\
\text { epicenter of } \\
\text { contamination }\end{array}$ & - & - & - \\
\hline
\end{tabular}

These data demonstrate that microscopic fungi cells have some differences in information characteristics of two areas of contaminated plant tissues.

The destruction of potato tuber tissue was maximally expressed in the epicenter of contamination. The redundancy coefficient R of Fusarium cells in this zone was 99,69\%. The redundancy coefficient $\mathrm{R}$ of Fusarium cells in peripheral area of potato tuber tissue contamination was slightly reduced to $99,4 \%$.

The values of information entropy $(H)$ of the microorganisms cells were 0,002 , the storage capacity $\left(\mathrm{H}_{\max }\right) 0,5$ in both areas of plant tissue contamination.

Previously we've obtained informative characteristics for yeast and bacteria cells producers of biotechnological foodstuff [19]. The information redundancy coefficient $\mathrm{R}$ was calculated for each type of microorganism.

For different yeast strains the values of redundancy coefficient R (\%) were:

Saccharomyces cerevisiae - 82,02; Mycoderma vini - 68,84; Rhodotorula gracilis 81,12. For different bacterial species the values of redundancy coefficient R (\%) were: Escherichia coli - 88,46; Baccilus subtilis - 65,94; Micrococcus sulfaticus - 49,29; Pseudomonas fluorescens - 38,83.

Comparative analysis of information characteristics of the researched microorganisms (Fusarium, yeast, bacteria) showed that the values of the redundancy

coefficient $\mathrm{R}$ in the Fusarium cells causing potato dry rot were higher in 1.3 times than that of yeast cells. The values of the redundancy coefficient $\mathrm{R}$ in the Fusarium cells causing potato dry rot were higher in 1.6 times than that of bacterial cells.

These data should be explained by some facts. The yeast strains and bacterial species were grown in a nutrient culture media prepared to ISO 11133-1-2011. The microorganisms were in resting state in culture media. The Fusarium cells have demonstrated low values of information entropy $H(0,002)$ compared to information capacity $\mathrm{H}_{\max }(0,5)$. The redundancy coefficient $\mathrm{R}$ in Fusarium cells had high values $(99,40 \%$ to $99,69 \%)$ thus demonstrated a high degree of orderliness and relative organization in microbial cells contaminating potato tubers. 


\section{— Food Technologies —}

It is known that phytopathogenic fungi of the genus Fusarium contaminating potato tubers are parasites. The fungi cells penetrate plant tissue and multiply in it by activating their metabolism [21]. Our research proves the maximum adaptation level of Fusarium cells in biocenosis with plant cells during microbial contamination of potato tubers.

It is important to study the Fusarium cell information characteristics in case of development and introduction new chemical and biological plant protecting preparations. It should be expected that in the case of the reaction of Fusarium cells on chemical or biological preparations the value of information entropy $\mathrm{H}$ should increase up to values of information capacity $\mathrm{H}_{\max }$, and the value of the redundancy coefficient $\mathrm{R}$ will decrease. This may be accured as a result of disruption structural and functional integrity of Fusarium cell system and will indicate the efficiency of new preparations .

\section{Conclusions}

The algorithm and the computer program based on morphometric analysis of Fusarium spp. macroconidium cells causing potato dry rot was created to study bioinformatic cell characteristics.

The values of bioinformatic cell characteristics such as the information entropy $(H)$, the storage capacity $\left(\mathrm{H}_{\max }\right)$ and the information redundancy coefficient $(\mathrm{R})$ were obtained to Fusarium spp. macroconidium cells causing potato dry rot.

The method of the bioinformatic modelling is demonstrated to help in study of adaptive reactions of Fusarium spp. causing potato dry rot and can be recommended as a testing system in development of new plant protecting preparations.

The method of the bioinformatic modelling can be recommended for the diagnostics of Fusarium infections in medicine.

The authors disclose that they have no conflict of interests.

\section{References}

1. Basyurkina N. (2013), Features of development of the agrofood market as main component of ensuring food security of Ukraine, Sotsial'no-ekonomicheskie yavleniya $i$ protsessy, 1, available at:

http://cyberleninka.ru/journal/n/sotsialno-ekonomicheskie-yavleniya-i-protsessy.

2. Kolchin N., Elizarov V. (2013), Potato Europe 2013: nastoyashchee i budushchee evropeyskogo kartofelya, Kartofel' $i$ ovoshchi, 10, pp. 30-32, available at: http://potatoveg.ru.

3. Bilay V. (1988), Mikroorganizmy - vozbuditeli bolezney rasteniy, Naukova dumka, Kyiv.

4. Liu Y., Wang N., Ye R., Kao W. (2013), Disseminated Fusarium infection in a patient with acute lymphoblastic leukemia: A case report and review of the literature, View Affiliations, pp. 334-336.

5. Esnakula A., Summers I., Naab T.(2013), Fatal disseminated Fusarium infection in a human immunodeficiency virus positive patient, Case Reports in Infectious Diseases, 2013, p. 5.

6. Martynova E., Ivanchenko O. (2015), Biologicheskie effekty fumonizinov $i$ kontaminatsiya imi zernoproduktov, Moscow. 
7. Pshechenkov K., Zeyruk V., Elanskiy S., Mal'tsev S. (2007), Tekhnologii khraneniya kartofelya, Kartofelevod, Moscow, available at:

http://www.kartofel.org/zakart/zakart_info.htm.

8. Heltoft P., Brurberg M.B., Skogen M., Le V.H., Razzaghian J., Hermansen A. (2016), Fusarium spp. causing Dry Rot on potatoes in Norway and development of a RealTime PCR method for detection of Fusarium coeruleum, Potato Research, 59.

9. Miru Du, Xiangyu Ren, Qinghua Sun, Yi Wang, Ruofang Zhang (2012). Characterization of Fusarium spp. causing potato Dry Rot in China and susceptibility evaluation of Chinese Potato germplasm to the pathogen, Potato Research, 55, pp. 175 -184 .

10. Stefanczyk E., Sobkowiak S., Brylinska M., Sliwka J.(2016), Diversity of Fusarium spp. associated with dry rot of potato tubers in Poland, European Journal of Plant Pathology, 144, pp. 1-14.

11. Statsenko A., Kapustin D. (2014), Rannyaya diagnostika infektsii v klubnyakh, Kartofel' $i$ ovoshchi, 4, p. 25, available at: http://potatoveg.ru.

12. Ryabinin A.(2013), Induktory bolezneustoychivosti protiv fitoftoroza, Kartofel' $i$ ovoshchi, 9, pp. 26-27, available at: http://potatoveg.ru.

13. Travina S., Abakshina S. (2014), Ekologicheskaya zashchita kartofelya ot fitoftoroza, Kartofel' $i$ ovoshchi, 2, pp.28-29, available at: http://potatoveg.ru.

14. Betts G., Walker S. (2004), Verification and validation of food spoilage models, Understanding and Measuring the Shelf-life of Food, Woodhead Publishing, Steele, R.- Cambridge, pp.185-217.

15. Zhilinskaya N., Shleikin A., Skobun A., Novozhilova A. (2013), Komp'yuternoe modelirovanie kompensatorno-vosstanovitel'nykh protsessov $\mathrm{v}$ neyronakh chernoy substantsii golovnogo mozga pri eksperimental'noy cherepno-mozgovoy travme, Matematicheskoe i komp'yuternoe modelirovanie v biologii i khimii. Perspektivy razvitiya, II Mezhdunarodnaya nauchnaya Internet-konferentsiya, Sistema virtual'nykh konferentsiy Pax Grid, Kazan, 1, pp. 71 - 75.

16. Areshidze D., Timchenko L. (2013), Analiz kompleksa informatsionnykh parametrov, kharakterizuyushchikh sostoyanie pecheni sobak reproduktivnogo vozrasta pri patologii, Vestnik Baltiyskogo federal'nogo universiteta im.I. Kanta, 7, pp. 44-50.

17. Isaeva N., Savin E., Subbotina T., Yashin A. (2013), Bioinformatsionnyy analiz tyazhesti morfologicheskikh izmeneniy $\mathrm{v}$ pecheni pri razlichnykh patologicheskikh protsessakh, Mezhdunarodnyy zhurnal prikladnykh i fundamental'nykh issledovaniy, 10, pp. 315-316.

18. Clive de W.Blackburn (2006), Food spoilage microorganisms, Woodhead publishing limited, Cambridge, England.

19. Zhilinskaya N., Shleikin A., Khamidova D. (2015), Primenenie metodov informatsionno-morfometricheskogo analiza pri issledovanii mikroorganizmov produtsentov biotekhnologicheskikh produktov, VII mezhdunarodnaya nauchnotekhnicheskaya konferentsiya "Nizkotemperaturnye $i$ pishchevye tekhnologii v XXI veke». Ch. II: Materialy konferentsii, Universitet ITMO, Sankt-Peterburg, pp. 272276.

20. Avtandilov G. (1990), Meditsinskaya morfometriya, Meditsina, Moscow.

21. Zamalieva F., Zaytseva T., Ryzhikh L., Salikhova Z. (2014), Epifitotiya fuzarioznogo uvyadaniya na kartofele v Srednem Povolzh'e, Kartofel'naya sistema, 1, available at: www.potatosystem.ru. 